\title{
Effects of the peroxisome proliferator-activated receptor- $\alpha$ agonists clofibrate and fish oil on hepatic fatty acid metabolism in weaned dairy calves ${ }^{1}$
}

\author{
N. B. Litherland, ${ }^{* 2}$ M. Bionaz, ${ }^{\star} †$ R. L. Wallace, $\ddagger$ J. J. Loor, ${ }^{*} \dagger$ and J. K. Drackley ${ }^{* 3}$ \\ *Department of Animal Sciences, \\ †Mammalian NutriPhysioGenomics, and \\ †Department of Veterinary Clinical Medicine, University of Illinois, Urbana 61801
}

\begin{abstract}
Peroxisome proliferator-activated receptor- $\alpha$ $(\operatorname{PPAR} \alpha)$ agonists increase fatty acid oxidation in liver of nonruminants. If similar effects occur in dairy cattle, enhanced hepatic oxidative capacity could decrease circulating nonesterified fatty acids and hepatic triacylglycerol accumulation in periparturient cows. The objectives of this study were 1) to determine whether partitioning of fatty acid metabolism by liver slices from weaned Holstein calves treated with PPAR $\alpha$ agonists in vivo is altered compared with partitioning by liver slices from control (untreated) calves, and 2) to measure in vitro metabolism of palmitate and oleate by bovine liver slices and relate these to mRNA abundance for key enzymes. Weaned male Holstein calves (7 wk old; $\mathrm{n}=15)$ were assigned to 1 of 3 groups for a 5 -d treatment period: control (untreated), clofibrate (62.5 $\mathrm{mg} / \mathrm{kg}$ of BW), or fish oil $(250 \mathrm{mg} / \mathrm{kg}$ of BW). Calves treated with clofibrate consumed less dry matter. Body weight, liver weight, liver weight:body weight ratio, blood nonesterified fatty acids, $\beta$-hydroxybutyrate, and liver composition were not significantly different among treatments. Liver slices were incubated for 2,4 , and 8 $\mathrm{h}$ to determine in vitro conversion of $\left[1-{ }^{14} \mathrm{C}\right]$ palmitate and $\left[1-{ }^{14} \mathrm{C}\right]$ oleate to $\mathrm{CO}_{2}$, acid-soluble products, esterified products, and total metabolism. In liver slices incubated for $8 \mathrm{~h}$, conversion of palmitate to $\mathrm{CO}_{2}$ was greater for calves treated with clofibrate compared with control calves or calves treated with fish oil. Conversion of palmitate to esterified products, total palmitate metabolism, and metabolism of oleate were not different among treatments. Conversion of palmitate to $\mathrm{CO}_{2}$ was greater than that from oleate for all treatments, but
\end{abstract}

\footnotetext{
Received September 10, 2009.

Accepted January 28, 2010.

${ }^{1}$ Supported by state and federal funds appropriated to the Illinois Agricultural Experiment Station, USDA-CSREES multistate research projects W-181 and W-1181.

${ }^{2}$ Current address: University of Minnesota, Department of Animal Science, 155B Haecker Hall, 1364 Eckles Avenue, St. Paul, MN 55108-

${ }^{3}$ Corresponding author: drackley@illinois.edu
} 6118 . rates of total metabolism did not differ. Clofibrate increased or tended to increase liver expression of several PPAR $\alpha$ target genes involved in fatty acid oxidation (e.g., ACADVL, ACOX1, CPT1A), whereas fish oil did not significantly affect genes associated with fatty acid oxidation but tended to increase DGAT1. Overall, our data indicated that bovine liver responded to clofibrate treatment but not fish oil, although increases in hepatic lipid metabolism were much less than those reported in rodents treated with clofibrate or fish oil. Applications of PPAR $\alpha$ agonists may be of interest to increase the rate of hepatic fatty acid oxidation and decrease triacylglycerol accumulation in periparturient dairy cows.

Key words: peroxisome proliferator-activated receptor- $\alpha$, liver, fatty acid metabolism, dairy calf

\section{INTRODUCTION}

Research during the last $20 \mathrm{yr}$ has focused on improving the health, well-being, and productivity of dairy cows during the transition period. Minimizing accumulation of triacylglycerol (TAG) in the liver (i.e., fatty liver) of periparturient cows is an important step toward meeting the goal of a smooth transition into lactation. Enhancing the ability of liver to oxidize long-chain fatty acids (LCFA) in mitochondria and peroxisomes should decrease TAG accumulation in the liver (Drackley and Andersen, 2006). Although less energetically efficient than mitochondrial $\beta$-oxidation, peroxisomal $\beta$-oxidation may be part of a strategy to dispose of increased NEFA flux during negative energy balance in cattle (Grum et al., 1994, 2002) as in other species (Osmundsen et al., 1991).

Peroxisome proliferator-activated receptors (PPAR) are nuclear proteins that belong to the superfamily of nuclear hormone receptors and function as liganddependent transcription factors. The PPAR mediate the effects of small lipophilic compounds such as LCFA and their derivatives on transcription of genes commonly called PPAR target genes. Upon ligand binding, PPAR heterodimerize with the retinoid $\mathrm{X}$ receptor and alter the transcription of target genes after binding to 
specific sequences in the promoter region called peroxisomal proliferator response elements. Therefore, PPAR control the expression of genes implicated in intra- and extracellular lipid metabolism, such as genes encoding enzymes involved in the mitochondrial and peroxisomal $\beta$-oxidation pathways (Schoonjans et al., 1996). The most abundant PPAR in liver (PPAR $\alpha$ ) plays a central role in the regulation of peroxisomal and mitochondrial fatty acid oxidation. Mice that lack functional PPAR $\alpha$ do not respond to PPAR $\alpha$ agonists and accumulate lipid in their livers (Lee et al., 1995).

Several natural and synthetic compounds can act as PPAR $\alpha$ agonists and increase the capacity of hepatocytes to oxidize LCFA by inducing mitochondrial and peroxisomal enzymes for $\beta$-oxidation (Green, 1995). A wide variety of LCFA, both saturated and unsaturated, can activate PPAR $\alpha$. In rodents, polyunsaturated LCFA are much more potent activators of PPAR $\alpha$ than are saturated LCFA (Kliewer et al., 1997).

Another group of compounds that are potent PPAR $\alpha$ agonists is the fibric acid derivatives such as clofibrate (Akbiyik et al., 2004). Clofibrate is a widely used hypolipidemic drug prescribed for prevention of coronary heart disease (Lee et al., 1995). Clofibrate increases hepatic peroxisomal $\beta$-oxidation in rats by as much as 10 times when either fed or injected daily (Lazarow and De Duve, 1976; Mannaerts et al., 1979). Feeding clofibrate at $1 \%$ of the diet for $14 \mathrm{~d}$ increased capacities for total and peroxisomal oxidation of palmitate in rats, but decreased the ratio of peroxisomal to total palmitate oxidation (Grum et al., 1994). In a rat fatty liver model, Akbiyik et al. (2003) showed that both a high-fat diet and clofibrate induced PPAR $\alpha$ expression in rat liver. Additionally, when added to the high-fat diet, clofibrate prevented development of fatty liver through induction of enzymes associated with LCFA oxidation in mitochondria and peroxisomes (Akbiyik et al., 2003). Clofibrate mediated a greater induction of PPAR $\alpha$ activation than did linoleic acid in rat and human hepatoma cell lines (Akbiyik et al., 2004).

The use of PPAR $\alpha$ agonists such as clofibrate has received little attention in ruminants. Cappon et al. (2002) measured increased peroxisomal $\beta$-oxidation activity in livers of lactating dairy goats orally treated with the PPAR $\alpha$ agonist Wy-14,643. Although PPAR $\alpha$ agonists have been researched thoroughly in humans and rodents, species differences must be taken into account when studying PPAR $\alpha$-mediated responses (Cheon et al., 2005). For example, recent in vitro studies with cultured Madin-Darby bovine kidney (MDBK) cells have provided evidence that ruminant PPAR $\alpha$ is less sensitive to chemical agonists and also may not activate the same genes as in rodents (Bionaz et al., 2008; Thering et al., 2009).
Our hypothesis was that PPAR $\alpha$ agonists, such as clofibrate or fish oil, would increase peroxisomal and mitochondrial $\beta$-oxidation in bovine liver. The objectives of this study were 1) to determine whether partitioning of fatty acid metabolism by liver slices from weaned Holstein calves treated with PPAR $\alpha$ agonists in vivo is altered compared with partitioning by liver slices from control calves, and 2) to measure in vitro metabolism of palmitate and oleate by bovine liver slices and relate these to mRNA abundance for key enzymes. Functional data for LCFA metabolism in liver slices, mRNA abundance, plasma metabolites, and liver composition may provide direct evidence as to whether clofibrate or fish oil have PPAR $\alpha$-activating activity in bovine liver, which in turn may provide a foundation for subsequent experiments with periparturient dairy cows.

\section{MATERIALS AND METHODS}

\section{Calf Management and Feeding}

All procedures involving animals were approved by the University of Illinois Institutional Animal Care and Use Committee. Fifteen male Holstein-Friesian calves were obtained on the day of birth or day after birth from a commercial dairy and transported to the Dairy Research Unit at the University of Illinois at UrbanaChampaign. Calves were obtained in blocks of $3 / \mathrm{wk}$ so that the technical demands for sample processing could be met. Calves were housed in individual calf hutches bedded with straw and had ad libitum access to water. Calves were fed twice daily a commercial milk replacer (Table 1) reconstituted to $12.5 \%$ solids with tap water. The milk replacer was fed at $10 \%$ of BW daily from d 1 to 3 and then at $12 \%$ of BW from d 4 until weaning. The evening milk replacer feeding was discontinued at the end of wk 4 and calves were weaned at the end of wk 5. Calves were fed starter grain (Table 1) for ad libitum consumption throughout the study. Samples of starter were taken weekly and pooled into 1 sample that was analyzed for contents of DM, CP, crude fat, $\mathrm{ADF}, \mathrm{NDF}, \mathrm{Ca}, \mathrm{P}, \mathrm{Mg}, \mathrm{K}$, and $\mathrm{Na}$ by a commercial laboratory (Dairy One, Ithaca, NY) Starter intake was measured for $5 \mathrm{~d}$ before initiation of treatment for covariate adjustment as well as throughout the 5-d treatment period. Calves were weighed weekly and were observed 3 times daily to evaluate health and well-being.

\section{Experimental Design and Treatments}

At 2 wk post-weaning (approximately $7 \mathrm{wk}$ of age), calves within each weekly block were randomly as- 
Table 1. Chemical composition ${ }^{1}$ of milk replacer and starter grain fed to weaned male Holstein calves

\begin{tabular}{lcc}
\hline Chemical, \% of DM & Milk replacer & Calf starter \\
\hline DM & 89.8 & 90.1 \\
CP & 20.4 & 19.5 \\
Crude fat & 23.2 & $\mathrm{ND}^{2}$ \\
ADF & ND & 7.4 \\
NDF & ND & 13.9 \\
Ash & 9.87 & ND \\
Ca & 1.24 & 0.79 \\
P & 0.78 & 0.47 \\
Mg & 0.15 & 0.19 \\
K & 2.13 & 1.22 \\
Na & 0.94 & 0.27 \\
\hline
\end{tabular}

${ }^{1}$ Analyzed by Dairy One Forage Testing Laboratory (Ithaca, NY).

${ }^{2} \mathrm{ND}=$ not determined

signed to 1 of 3 experimental groups for a 5 -d treatment period ( $\mathrm{n}=5$ per group). Treatments were 1 ) control (untreated), 2) oral administration of clofibrate (62.5 $\mathrm{mg} / \mathrm{kg}$ of $\mathrm{BW}$ ), and 3) oral administration of fish oil $(250 \mathrm{mg} / \mathrm{kg}$ of BW). The daily dose of clofibrate was divided into 3 equal portions that were delivered via nipple bottle 3 times daily; each portion was mixed with $50 \mathrm{~g}$ of milk replacer powder and $1 \mathrm{~L}$ of water for each dose. The daily dose of fish oil was divided into 2 equal portions that were delivered twice daily in \#10 gelatin capsules (Torpac Inc., Fairfield, NJ) for $5 \mathrm{~d}$. The LCFA composition of fish oil (Table 2) was determined by converting LCFA to methyl esters (Sukhiha and Palmquist, 1988) that were separated on a gas chromatograph (GC-17A, Shimadzu Corporation, Kyoto, Japan) equipped with an auto sampler, a flame ionization detector, and a fused silica capillary column $(100 \mathrm{~m} \times 0.25 \mathrm{~mm}$ i.d.; SP-2380, Supelco, Bellefonte, PA).

In our preliminary experiments, the protocol for treatment administration was to administer $125 \mathrm{mg}$ of clofibric acid $/ \mathrm{kg}$ of BW (Akbiyik et al., 2003) once daily via an oral bolus in a gelatin capsule. To our knowledge, no reports of administration of clofibric acid to ruminants had been published before this study. The first calf treated with clofibric acid showed dramatically reduced feed intake on the first day of administration and died on the evening of the second day of administration. This calf was outwardly healthy before treatment and necropsy results revealed no gross disorders. A search of the available literature regarding clofibric acid suggested that the compound may be toxic to some anaerobic bacteria (Dokianakis et al., 2004; Fountoulakis et al., 2004; Drillia et al., 2005). We speculate that oral administration of clofibric acid resulted either in a large alteration of the microbial ecology of the rumen or in production and subsequent absorption of a toxic intermediary metabolite from the microbial metabolism of clofibric acid. A large shift in the rumen ecology is not likely to cause acute death; however, production of a toxic intermediate metabolite is plausible and may explain the cause of death of the calf.

Consequently, the treatment protocol for the main experiment was changed by switching from clofibric acid to the less soluble form clofibrate and reducing the original dosage from $125 \mathrm{mg} / \mathrm{kg}$ of BW to $62.5 \mathrm{mg} / \mathrm{kg}$ of BW daily. Additionally, administration was switched from a once-daily bolus of $125 \mathrm{mg} / \mathrm{kg}$ of BW to administration 3 times daily of 3 equal doses, delivered in liquid via nipple bottle, to total $62.5 \mathrm{mg} / \mathrm{kg}$ of BW. Although lower than our original selected dosage, this amount still is within the range of doses shown to be effective in rodent models. Delivery of the clofibrate solution via the nipple bottle may have helped bypass the rumen via the reticular groove reflex. Lower solubility of clofibrate compared with clofibric acid may have resulted in less alteration of the chemical structure by the rumen microbes for any compound that reached the rumen. Effects of lower solubility of clofibrate on absorption of the drug in the lower gut and resultant treatment responses are unknown. Calves readily consumed the clofibrate-containing milk replacer mixture and no outward negative effects on health were observed after this revised treatment protocol was implemented.

Table 2. Fatty acid composition of fish oil ${ }^{1}$ orally dosed twice daily to weaned male Holstein calves

\begin{tabular}{lc}
\hline Fatty acid & $\begin{array}{c}\mathrm{g} / 100 \mathrm{~g} \text { of } \\
\text { fatty acid }\end{array}$ \\
\hline C12:0 & 0.21 \\
C14:0 & 17.66 \\
C15:0 $16: 0$ & 1.02 \\
C16:1 & 17.39 \\
C17:0 & 22.43 \\
C17:1 $18: 0$ & 0.43 \\
C18:1 trans-9 & 2.95 \\
C18:1 cis-9 $18: 1$ cis-11 & 2.33 \\
C18:2 cis-9, cis-12 $18: 3$ n-6 & 1.63 \\
C18:3 n-3 & 6.32 \\
C20:1 & 3.86 \\
C20:3 n-6 & 1.47 \\
C20:4 n-6 & 0.51 \\
C23:0 n-3 & 1.14 \\
C20:5 n-3 & 0.62 \\
C24:1 & 0.21 \\
C22:6 n-3 & 0.70 \\
Unidentified & 1.11 \\
Total & 9.36 \\
\hline
\end{tabular}

${ }^{1}$ Virginia Prime-Gold, Omega Protein (Hammond, LA). 


\section{Tissue Collection}

Calves were fasted overnight and weighed immediately before euthanasia and collection of liver tissue the following morning. Calves were killed by captive bolt followed by exsanguination. The entire liver (minus the gall bladder) was removed and weighed immediately after calves were killed. Data were then used to calculate relative liver weight as a proportion of BW. Samples of liver were frozen immediately in liquid $\mathrm{N}_{2}$ and later analyzed for contents of total lipid (Hara and Radin, 1978), TAG (Fletcher, 1968; Foster and Dunn, 1973), and glycogen (Lo et al., 1970). Portions of the liver were prepared for isolation of total RNA for real time reverse transcription-PCR (qPCR) measurement of mRNA abundance.

\section{In Vitro Fatty Acid Metabolism}

In vitro procedures were a modification of those used by Drackley et al. (1991). The entire liver from each calf was transported on ice to the laboratory, where cores of liver tissue were prepared using a coring tool $(10 \mathrm{~mm}$ diameter) and placed in ice-cold phosphate buffered $0.9 \% \mathrm{NaCl}$ at $\mathrm{pH}$ 7.4. Liver slices were prepared from the cores of liver tissue using a Krumdieck tissue slicer (Alabama Research and Development, Munford, AL) equipped with a tissue holder (10 $\mathrm{mm}$ diameter). Two slices (approximately $40 \mathrm{mg}$ ) were blotted and weighed into a 25-mL incubation flask for a total of approximately $80 \mathrm{mg}$ of tissue per flask. All incubations were performed in duplicate. Liver slices were incubated in 3 $\mathrm{mL}$ of RPMI-1640 medium (Sigma-Aldrich, St. Louis, $\mathrm{MO}$ ) at a concentration of $8.4 \mathrm{~g} / \mathrm{L}$ with $2 \mathrm{~g} / \mathrm{L}$ of sodium bicarbonate. Substrates were either sodium palmitate $(2 \mathrm{mM})$ with $0.3 \mu \mathrm{Ci}$ of $\left[1-{ }^{14} \mathrm{C}\right]$ palmitic acid (American Radiochemicals, Oviedo, FL) or sodium oleate (2 $\mathrm{mM}$ ) with $0.3 \mu \mathrm{Ci}$ of $\left[1-{ }^{14} \mathrm{C}\right]$ oleic acid (American Radiochemicals). Each fatty acid substrate was complexed to fatty acid-free BSA in a 4:1 molar ratio. L-Carnitine $(1 \mathrm{mM})$ and an antibiotic-antimycotic solution (A5955, Sigma-Aldrich; $1 \%$ of the final media) were added to the medium.

Production of acid-soluble products $(\mathbf{A S P})$ and $\mathrm{CO}_{2}$ from radiolabeled LCFA were measured simultaneously in the same flask. A hanging plastic well containing a folded piece of filter paper was inserted to collect $\mathrm{CO}_{2}$. Plastic $\mathrm{CO}_{2}$ wells were made of 1 -mL microcentrifuge tubes containing half of a piece of folded \#1 Whatman filter paper $(42.5 \mathrm{~mm})$ and were suspended within each flask using nylon monofilament. After tissue loading was complete, flasks containing liver were gassed with 95:5 $\mathrm{O}_{2}: \mathrm{CO}_{2}$, sealed with a rubber septum, and incubated in a shaking water bath at $37^{\circ} \mathrm{C}$ for 2 , 4 , or
8 h. Incubations were terminated by injecting $0.5 \mathrm{~mL}$ of $40 \%$ (wt/vol) $\mathrm{HClO}_{4}$ acid followed by injection of $0.1 \mathrm{~mL}$ of $30 \% \mathrm{NaOH}$ onto the suspended filter paper for collection of $\mathrm{CO}_{2}$. Flasks were shaken on ice for $1 \mathrm{~h}$ following termination of the incubation to collect evolved $\mathrm{CO}_{2}$. After the 1-h collection of $\mathrm{CO}_{2}$, the entire $\mathrm{CO}_{2}$ well was placed in a scintillation vial and $10 \mathrm{~mL}$ of liquid scintillation cocktail (Scintisafe Econo 2, Fisher Scientific, Waltham, MA) was added to each vial; vials then were counted in a liquid scintillation spectrophotometer (Beckman LS 6000 IC, Beckman Coulter Inc., Brea, CA) to measure complete oxidation of palmitate to $\mathrm{CO}_{2}$.

Flasks containing media, tissue, and acid were allowed to warm to room temperature and were then poured into $10-\mathrm{mL}$ tubes that were centrifuged for $10 \mathrm{~min}$ at $2,000 \times g$. One milliliter of the resulting supernatant was transferred to a second tube and neutralized to pH 7 with $2 \mathrm{M} \mathrm{K}_{2} \mathrm{CO}_{3}$; the tube then was centrifuged again for $5 \mathrm{~min}$ at $2,000 \times \mathrm{g}$. Incomplete oxidation of palmitate to ASP $(\sim 80 \%$ ketone bodies and acetate; Jesse et al., 1986) was measured by counting $0.5 \mathrm{~mL}$ of the resulting supernatant. Blank flasks containing medium but no tissue were prepared concurrently for both palmitate and oleate media.

Esterification of palmitate and oleate was measured in liver slices as described previously (Drackley et al., 1991; Carlson et al., 2006). Liver slices were incubated in a manner identical to measurements of palmitate and oleate oxidation except that no hanging wells were used and incubations were terminated by aspirating the media from the tissue and immediately placing the flasks on ice. Slices were rinsed 3 times with $3 \mathrm{~mL}$ of $37^{\circ} \mathrm{C}$ Krebs-Ringer bicarbonate buffer with $3 \%$ BSA and 4 times with $1 \mathrm{~mL}$ of $0.9 \% \mathrm{NaCl}$. Liver slices were then transferred into $5 \mathrm{~mL}$ of hexane:isopropanol [2:1 (vol/vol)] in screw-top extraction tubes that were gently shaken overnight on a wrist-action shaker. The next morning ( $\sim 12 \mathrm{~h}$ later), tissue slices were reextracted with an additional $2 \mathrm{~mL}$ of hexane:isopropanol [2:1 (vol/vol)], which was combined with the initial volume. Five milliliters of sodium sulfate solution $(0.05 M)$ was added to the extraction tubes, which then were vortexed before being centrifuged for 5 min at 1,200 $\times g$. The organic solvent layer was transferred to a scintillation vial and dried under moving air. When dry, 10 $\mathrm{mL}$ of scintillation cocktail (Scintisafe Econo 2, Fisher Scientific) was added to each vial and radioactivity in total esterified products (EP) was determined by liquid scintillation spectroscopy (model LS6000 IC, Beckman Coulter Inc.). Blank flasks, to which liver slices were added followed by immediate aspiration of media and placement of the flask on ice, were processed in parallel to incubated flasks. Average rates of duplicate flasks 
were corrected for background radioactivity by subtracting values obtained from blank flasks.

Data were expressed as nanomoles of palmitate or oleate converted to product $\left(\mathrm{CO}_{2}, \mathrm{ASP}\right.$, or $\left.\mathrm{EP}\right)$ per gram of liver (wet weight), and the sum of the 3 products is reported as total metabolism of palmitate or oleate. Although expression of metabolic activity relative to tissue protein or DNA content may be more accurate where changes in tissue composition occur (e.g., Graulet et al., 2000), we anticipated that alterations in tissue composition would be minimal in the weaned calves used in this experiment. Additionally, $\mathrm{CO}_{2}, \mathrm{ASP}$, and EP produced by liver slices were expressed as percentages of total metabolism.

\section{Isolation of RNA and Reverse Transcription-PCR of Specific mRNA}

Total RNA was extracted from 1.0 to $1.5 \mathrm{~g}$ of liver placed in 10 to $15 \mathrm{~mL}$ of ice-cold Trizol reagent (Invitrogen, Carlsbad, CA). The mixture was homogenized and RNA was extracted as previously reported (Loor et al., 2005). Extracted RNA was resuspended in RNA storage buffer (Ambion Inc., Austin, TX) and stored at $-80^{\circ} \mathrm{C}$ until analysis. Prior to cDNA synthesis, total RNA was purified with the RNeasy mini kit (Qiagen, Valencia, CA) and residual DNA was removed using the RNase-Free DNase set (Qiagen).

The cDNA synthesis and $\mathrm{qPCR}$ were performed as described previously (Bionaz and Loor, 2008) except that the mRNA abundance of the internal control gene (ICG) selected, PPIA (peptidylprolyl isomerase A), was determined on each plate. Table 3 reports features of primers to specifically amplify 6 potential PPAR $\alpha$ target genes $\{\boldsymbol{A} \boldsymbol{C A} \boldsymbol{D} \boldsymbol{V L}$ [acyl-coenzyme A dehydrogenase, very long chain], $\boldsymbol{A} \boldsymbol{C S \boldsymbol { S } 1}$ [acyl-coenzyne A synthetase long-chain family member 1], $\boldsymbol{A} \boldsymbol{C O X} \mathbf{1}$ [acyl-coenzyme

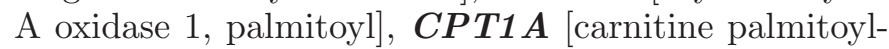
transferase 1A (liver)], $\boldsymbol{C} \boldsymbol{Y P} 4 \boldsymbol{A 1 1}$ [cytochrome P450, family 4, subfamily A, polypeptide 11], and $\boldsymbol{P P A R A}$ [peroxisome proliferator-activated receptor- $\alpha$ ] (Mandard et al., 2004), plus 2 genes involved in TAG synthesis [DGAT1 (diacylglycerol O-acyltransferase homolog 1) and GPAM (glycerol-3-phosphate acyltransferase, mitochondrial)] and 4 test ICG $[A C T B$ (actin $\beta$ ), $G A P D$ (glyceraldehyde-3-phosphate dehydrogenase), PPIA, and RPS9 (ribosomal protein s9)]. The primer pair for $C Y P 4 A 11$ was designed using Primer Express Software (version 2.0; Applied Biosystems, Foster City, CA). Among the 4 ICG tested, PPIA was chosen to normalize the qPCR results in the present experiment based on constancy of expression ratios among samples using geNorm software (http://medgen.ugent. be/ jvdesomp/genorm/), essentially as described by Janovick-Guretzky et al. (2007).

\section{Blood Sampling and Analysis}

Plasma and serum samples were collected from a jugular vein at $1300 \mathrm{~h}$ on the day before initiation of treatment and again at $1300 \mathrm{~h}$ on d 5 of treatment. Plasma samples were collected into evacuated tubes containing sodium heparin (Becton Dickinson Vacutainer Systems, Franklin Lakes, NJ). Plasma was obtained by centrifugation at $1,300 \times g$ for $10 \mathrm{~min}$. Aliquots of plasma were frozen at $-20^{\circ} \mathrm{C}$ until later analysis for BHBA (Williamson and Mellanby, 1974; Ranbut kit, Randox Laboratories Ltd., Oceanside, CA), glucose (Peterson and Young, 1968; glucose/ HK kit, Roche, Basel, Switzerland), total cholesterol (Allain et al., 1974; cholesterol/HP kit, Roche), urea N (Talke and Schubert, 1965; urea/BUN kit, Roche), total protein (Weichselbaum, 1945; total protein kit, Roche), total bilirubin (Wahlefeld et al., 1972; total bilirubin kit, Roche), alkaline phosphatase (Tietz et al.,1983; alkaline phosphatase IFCC liquid kit, Roche), aspartate aminotransferase (Bergmeyer et al., 1986; AST kit, Roche), $\gamma$-glutamyl transferase (Persijn and van der Slik, 1976; GGT Szasz liquid kit, Roche), and sorbitol dehydrogenase (Rose and Henderson, 1975; SDH kit, Diagnostic Chemicals Limited, Charlottetown, Prince Edward Island, Canada) at the University of Illinois College of Veterinary Medicine Diagnostic Laboratory on an auto-analyzer using assays validated for bovine plasma. Concentrations of NEFA in plasma were determined enzymatically using a commercial kit (NEFA C kit, Wako Chemicals USA Inc., Richmond VA) as modified by Johnson and Peters (1993).

Serum was obtained by collecting blood into evacuated serum tubes (SST, Becton Dickinson Vacutainer Systems) containing clot activator and was processed using the same methods as those used to obtain plasma. Serum insulin was measured using a radioimmunoassay kit (Coat-a-Count insulin kit, Diagnostic Products Corporation, Los Angeles, CA) as modified by Studer et al. (1993).

\section{Statistical Analysis}

Data for all analyses were blocked by the week calves were purchased. Before statistical analysis, data were tested for outliers (data points with studentized residuals >2.5) using PROC REG of SAS (SAS Institute, Cary, NC). In addition, data without outliers were assessed for normal distribution using PROC UNIVARIATE NORMAL of SAS with Shapiro Wilk (W) and 
Table 3. GenBank accession number, gene symbol, hybridization position, sequence, length of the amplicon in base pairs, and reference for the primers used

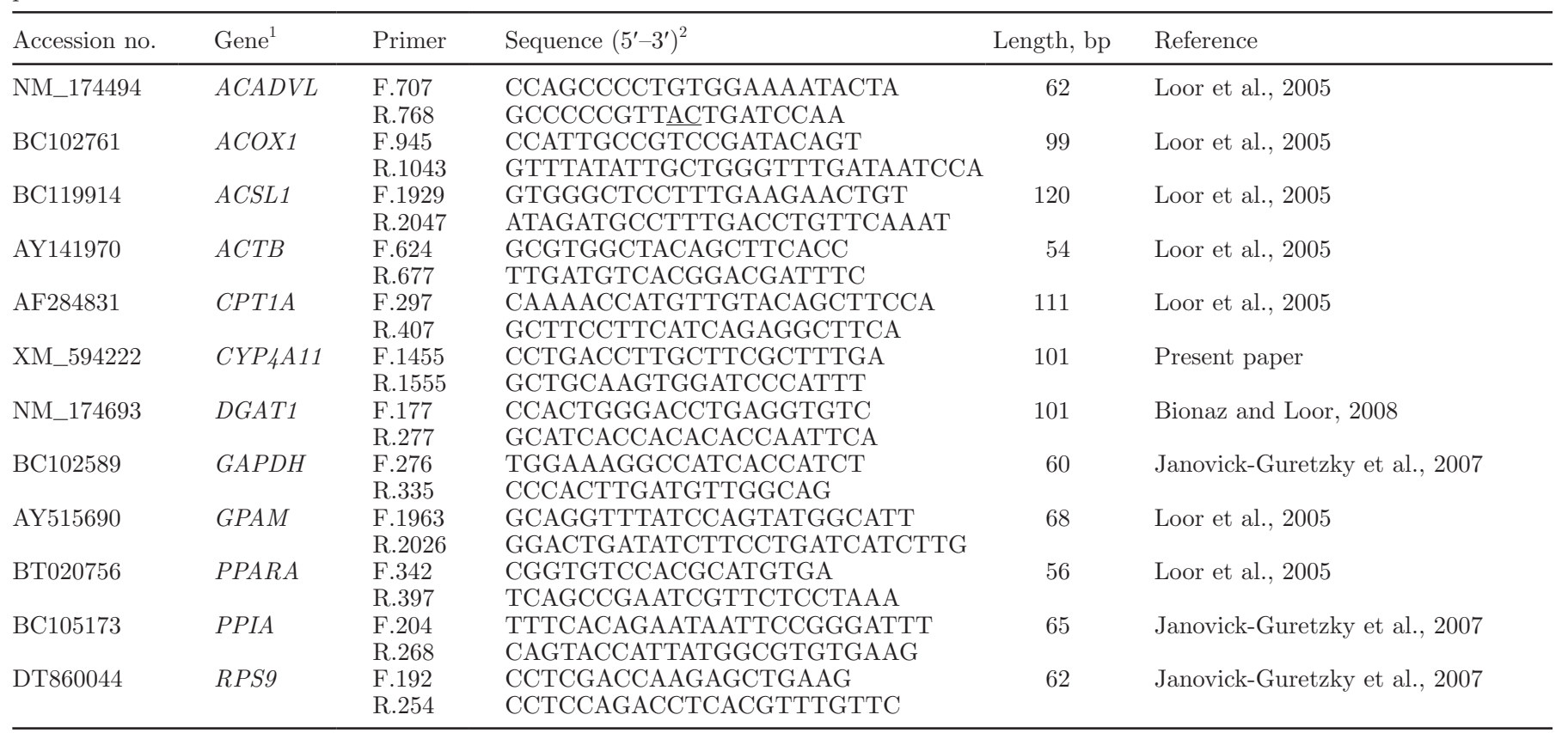

${ }^{1} A C A D V L=$ acyl-coenzyme A dehydrogenase, very long chain; $A C O X 1=$ acyl-coenzyme A oxidase 1 , palmitoyl; $A C S L 1=$ acyl-coenzyme $\mathrm{A}$ synthetase long-chain family member $1 ; A C T B=$ actin $\beta ; C P T 1 A=$ carnitine palmitoyltransferase $1 \mathrm{~A}$ (liver); $C Y P 4 A 11=$ cytochrome $\mathrm{P} 450$, family 4, subfamily A, polypeptide 11; DGAT1 = diacylglycerol O-acyltransferase homolog 1; GPAM= glycerol-3-phosphate acyltransferase, mitochondrial; PPARA = peroxisome proliferator-activated receptor- $\alpha ; P P I A=$ peptidylprolyl isomerase A; RPS9= ribosomal protein s9.

${ }^{2}$ Exon-exon junction of reverse $A C A D V L$ primer is underlined.

Kolmogorov-Smirnov (D) tests. Data were considered normally distributed when the $P$-value of $\mathrm{W}$ and $\mathrm{D}$ were $>0.01$. Data were subjected to ANOVA by using the MIXED procedure of SAS (release 8.2; Littell et al., 1996). The model for in vitro liver slice metabolism included effects of block (as a random effect), treatment (control, $\mathrm{n}=5$; clofibrate, $\mathrm{n}=4$; fish oil, $\mathrm{n}=$ $5)$, length of incubation $(2,4$, or $8 \mathrm{~h})$, and the interaction between treatment and length of incubation. The appropriate covariance structure was identified by the use of Akaike's information criterion. Where significant interactions of treatment and incubation time occurred, means were separated by use of the PDIFF statement. For comparison of palmitate versus oleate metabolism, the same model was used with fatty acid as a fixed effect, length of incubation as a repeated effect, and fatty acid by calf within block as a subject. Significant model effects $(P<0.05)$ were separated by using the PDIFF statement. Blood measurements and starter intake were adjusted using respective blood samples before initiation of treatment and average starter intake for $5 \mathrm{~d}$ before initiation of treatment as covariates in a model that contained the effects of block (as a random variable) and treatment.

The normalized qPCR data were transformed as $n$ fold change relative to control as previously reported
(Bionaz and Loor, 2008). To estimate standard errors for controls and to prevent biases in statistical analysis, normalized data were transformed to obtain a perfect average of 1.0 for controls, leaving the proportional difference among the biological replicates. The same proportional change was calculated for the other treatments to obtain an $n$-fold change relative to controls. Among all tested genes, only $A C A D V L$ was not normally distributed and data were $\log _{10}$-transformed before analysis, plus addition of 1 to avoid negative numbers. Data for this gene are shown as $\log _{10}$-transformed +1 in graphs. The final data set was analyzed using the MIXED procedure of SAS. The model included treatment (clofibrate, $\mathrm{n}=4$; control, $\mathrm{n}=5$; fish oil, $\mathrm{n}=5$ ) and calf within treatment as a random effect. Significant effects of treatment $(P<0.05)$ were separated by use of the PDIFF statement in SAS. Effects of treatment with $P<0.10$ are discussed as trends.

\section{RESULTS AND DISCUSSION}

Final BW, liver weight, and liver weight:BW ratio were not significantly different among treatments (Table 4). Calves treated with clofibrate $(P=0.05)$ consumed less starter than untreated or fish oil-treated calves (Table 4 ). Treatment with clofibrate tended ( $P$ 
Table 4. Least squares means for BW, liver weight, ratio of liver weight to BW, and starter intake for Holstein male calves either untreated (control) or treated with clofibrate or fish oil

\begin{tabular}{|c|c|c|c|c|c|}
\hline \multirow[b]{2}{*}{ Item } & \multicolumn{3}{|c|}{ Treatment $^{1}$} & \multirow[b]{2}{*}{$\mathrm{SE}$} & \multirow[b]{2}{*}{$P$-value (treatment) } \\
\hline & Control & Clofibrate & Fish oil & & \\
\hline $\mathrm{BW}, \mathrm{kg}$ & 56.9 & 56.0 & 62.8 & 6.2 & 0.70 \\
\hline Liver weight, $\mathrm{kg}$ & 1.1 & 1.7 & 1.3 & 0.3 & 0.31 \\
\hline Liver weight:BW ratio & $0.019^{\mathrm{y}}$ & $0.030^{\mathrm{x}}$ & $0.020^{\mathrm{y}}$ & 0.003 & 0.06 \\
\hline Starter intake, $\mathrm{kg} / \mathrm{d}$ & $1.6^{\mathrm{a}}$ & $1.1^{\mathrm{b}}$ & $1.4^{\mathrm{a}}$ & 0.1 & 0.05 \\
\hline
\end{tabular}

$=0.06)$ to increase the ratio of liver weight to BW. Treatment of rodents with clofibrate frequently has resulted in increased liver weight because of hepatocyte proliferation (Shoda et al., 1999; Qu et al., 2000). Jones et al. (1999) observed a $42 \%$ increase in liver weight:BW ratio in clofibrate-treated rats. Liver size increased by $38 \%$ in neonatal piglets treated with clofibrate (Peffer et al., 2005).

Concentrations of NEFA, glucose, BHBA, urea N, cholesterol, total protein, insulin, and bilirubin as well as activities of aspartate aminotransferase, sorbitol dehydrogenase, and $\gamma$-glutamyl transferase in plasma did not differ significantly among treatments (Table 5). Treatment of lactating goats with $\mathrm{Wy}-14,643$ resulted in significant reductions in both serum glucose and cholesterol (Cappon et al., 2002). Large changes in energy-yielding metabolites (NEFA, BHBA, and glucose) were not anticipated in the weaned calves used in this experiment. Activity of alkaline phosphatase in plasma tended $(P=0.07)$ to decrease in clofibratetreated calves. Alkaline phosphatase (ALP) in serum originates from liver and bone and can be used as an index of liver function or bone metabolism in cattle (Carlson, 1996). Serum ALP activity increases in cases of hepatitis or biliary disorders or during growth because of active bone metabolism (Carlson, 1996). Reasons for the tendency for decreased ALP in clofibrate-treated calves are unclear; at the least, these data indicate that liver function was not impaired by clofibrate and perhaps indicate improvement in overall liver health.

Concentrations of total lipid, TAG, and glycogen in liver and the TAG:glycogen ratio were not significantly different among treatments (Table 6). Clofibrate administration to mice decreased liver lipid content and altered liver fatty acid composition (Pennacchiotti et al., 1996). Large differences in liver composition were not expected in the calf model employed in this study. The slight (nonsignificant) difference in total lipid concentration in liver may have been attributable to the tendency toward lower starter intake in the clofibratetreated calves, resulting in lower energy intake.

Slices of liver were incubated for 2,4 , and $8 \mathrm{~h}$. Incubation time points for this study were chosen to test potential short-term and longer term differences among

Table 5. Least squares means and standard errors for concentrations of metabolites, hormones, and liverrelated enzymes in plasma from male Holstein calves either untreated (control) or treated with clofibrate or fish oil

\begin{tabular}{|c|c|c|c|c|c|}
\hline \multirow[b]{2}{*}{ Variable } & \multicolumn{3}{|c|}{ Treatment $^{1}$} & \multirow[b]{2}{*}{$\mathrm{SE}$} & \multirow[b]{2}{*}{$P$-value (treatment) } \\
\hline & Control & Clofibrate & Fish oil & & \\
\hline NEFA, $\mu \mathrm{Eq} / \mathrm{L}$ & 75.6 & 61.6 & 69.4 & 9.7 & 0.63 \\
\hline Glucose, $\mathrm{mg} / \mathrm{dL}$ & 81.2 & 82.9 & 85.7 & 6.0 & 0.73 \\
\hline $\mathrm{BHBA}, \mathrm{m} M$ & 0.74 & 0.33 & 0.61 & 0.1 & 0.18 \\
\hline Urea $\mathrm{N}, \mathrm{mg} / \mathrm{dL}$ & 7.5 & 6.3 & 7.1 & 0.7 & 0.45 \\
\hline Cholesterol, $\mathrm{mg} / \mathrm{dL}$ & 52.0 & 48.3 & 54.8 & 5.3 & 0.64 \\
\hline Total protein, $\mathrm{g} / \mathrm{dL}$ & 6.6 & 6.2 & 6.6 & 0.2 & 0.29 \\
\hline Insulin, $\mu \mathrm{IU} / \mathrm{mL}$ & 9.0 & 3.9 & 4.6 & 1.9 & 0.12 \\
\hline Bilirubin, mg/dL & 0.3 & 0.4 & 0.4 & 0.04 & 0.38 \\
\hline Alkaline phosphatase, U/L & 252.6 & 181.4 & 268.7 & 25.7 & 0.068 \\
\hline Aspartate aminotransferase, $\mathrm{U} / \mathrm{L}$ & 86.3 & 53.9 & 72.0 & 16.1 & 0.32 \\
\hline$\gamma$-Glutamyl transferase, U/L & 18.9 & 19.2 & 18.6 & 1.5 & 0.96 \\
\hline Sorbitol dehydrogenase, U/L & 37.5 & 15.4 & 33.4 & 7.0 & 0.11 \\
\hline
\end{tabular}

${ }^{1}$ Calves received a treatment of control (untreated), clofibrate $(62.5 \mathrm{mg} / \mathrm{kg}$ of BW), or fish oil $(250 \mathrm{mg} / \mathrm{kg}$ of BW) for a 5-d treatment period. 
Table 6. Least squares means and standard errors for concentrations of total lipid, triacylglycerol, and glycogen in liver from male Holstein calves either untreated (control) or treated with clofibrate or fish oil

\begin{tabular}{lccccc}
\hline & \multicolumn{4}{c}{ Treatment $^{1}$} \\
\cline { 2 - 4 } Variable & Control & Clofibrate & Fish oil & SE & $P$-value (treatment) \\
\hline Total lipid, \% wet weight & 3.81 & 4.19 & 3.82 & 0.14 & 0.13 \\
Triacylglycerol, \% wet weight & 0.20 & 0.26 & 0.21 & 0.05 & 0.62 \\
Glycogen, \% wet weight & 0.34 & 0.31 & 0.36 & 0.07 & 0.86 \\
Triacylglycerol:glycogen & 0.75 & 0.89 & 0.66 & 0.25 & 0.78 \\
\hline${ }^{1}$ Calves received a treatment of control (untreated), clofibrate $(62.5 \mathrm{mg} / \mathrm{kg}$ of $\mathrm{BW})$, or fish oil $(250 \mathrm{mg} / \mathrm{kg}$ of \\
BW) for a 5-d treatment period.
\end{tabular}

treatments. We were limited to 3 time points because of the physical constraint of the number of flasks that could be incubated and processed on a given day of experimentation. The primary end products of LCFA oxidation are $\mathrm{CO}_{2}$ and ketone bodies. Complete oxidation of the carboxyl carbon of palmitate by liver slices was measured as $\left[1-{ }^{14} \mathrm{C}\right]$ palmitate carbon incorporated into $\mathrm{CO}_{2}$. Conversion of palmitate to $\mathrm{CO}_{2}$ increased significantly $(P<0.05)$ over time of incubation (Figure 1A) and the interaction between treatment and incubation time was significant $(P<0.05)$. There was no significant difference among treatments for $\mathrm{CO}_{2}$ in 2- or 4-h incubations. In 8-h incubations, liver slices from clofibrate-treated calves had greater $(P<0.05)$ rates of palmitate conversion to $\mathrm{CO}_{2}$ than those from control or fish-oil treated calves, indicating that differences among treatments required a longer period of incubation $(>4 \mathrm{~h})$. Increased rate of conversion of palmitate to $\mathrm{CO}_{2}$ indicates increased mitochondrial capacity to perform $\beta$-oxidation. Rates of $\mathrm{CO}_{2}$ production from liver slices from these calves were similar to rates reported by Piepenbrink and Overton (2003) for 2-h incubations of liver slices from periparturient Holstein cows; incubations were conducted in different medium, but otherwise with similar methods. Incomplete oxidation of palmitate through ketogenesis, measured as ASP, was different $(P<0.05)$ among incubation times but did not differ among treatments (Figure 1B). Conversion of palmitate to esterified products increased $(P<0.05)$ over time (Figure $1 \mathrm{C})$, but no significant differences among treatments were observed. Increased rates of oxidation as indicated by increases in the yield of $\mathrm{CO}_{2}$ suggest that liver from calves treated with the PPAR a agonist clofibrate had modestly greater capacity to oxidize LCFA when compared with liver from untreated calves.

Total palmitate metabolism by liver slices, defined as the sum of rates of palmitate conversion to $\mathrm{CO}_{2}$, ASP, and EP, tended $(P=0.08)$ to be different among incubation times but was not different among treatments (Figure 1D). Expression of palmitate metabolism rates as percentages of total palmitate metabolism is a useful basis to determine differences in partitioning of metabolic capacity among $\mathrm{CO}_{2}$, ASP, and EP when substrate is not limiting. As a percentage of total palmitate metabolism, there was a significant interaction between treatment and incubation time for palmitate conversion to $\mathrm{CO}_{2}$ because liver slices from calves treated with clofibrate had a greater $(P<0.05)$ proportion of palmitate converted to $\mathrm{CO}_{2}$ at $8 \mathrm{~h}$ than liver slices from control calves and calves treated with fish oil (Table 7). Proportions of products as ASP or EP were not different among treatments.

Conversion of oleate to $\mathrm{CO}_{2}$ increased $(P<0.05)$ with greater incubation lengths, but there was no difference among treatments (Figure $2 \mathrm{~A}$ ) because variability among individual calves was high. Oleate metabolism to ASP and EP and total oleate metabolism by liver slices were different $(P<0.05)$ among time points but did not differ among treatments (Figures 2). Metabolism of oleate to $\mathrm{CO}_{2}, \mathrm{ASP}$, or EP as percentages of total oleate metabolism also did not differ significantly among treatments (Table 8).

Comparison of rates of metabolism between palmitate and oleate (Figures 1 and 2) showed that both LCFA were metabolized at similar rates by liver slices. Only oxidation to $\mathrm{CO}_{2}$ differed between LCFA, with oxidation of palmitate being greater than that of oleate $(P<0.05)$. Few comparisons of rates of oxidation of LCFA have been made in bovine liver. Mashek et al. (2002) found that oxidation of oleate to $\mathrm{CO}_{2}$ was not significantly greater than oxidation of palmitate in short-term suspension cultures of hepatocytes isolated from preweaned calves. Esterification rates were similar between these LCFA. Similar rates of metabolism between these 2 substrates is logical given that they are the most abundant LCFA in adipose TAG and, as a result, in NEFA mobilized from adipose tissues (Rukkwamsuk et al., 2000; Douglas et al., 2007).

Increases in oxidative products caused by PPAR $\alpha$ agonist treatment were lower than expected. Hepatic $\beta$-oxidation was approximately 3 times greater in lactating goats administered the PPAR $\alpha$ agonist Wy-14,643 (a more potent agonist than clofibrate) than in control 

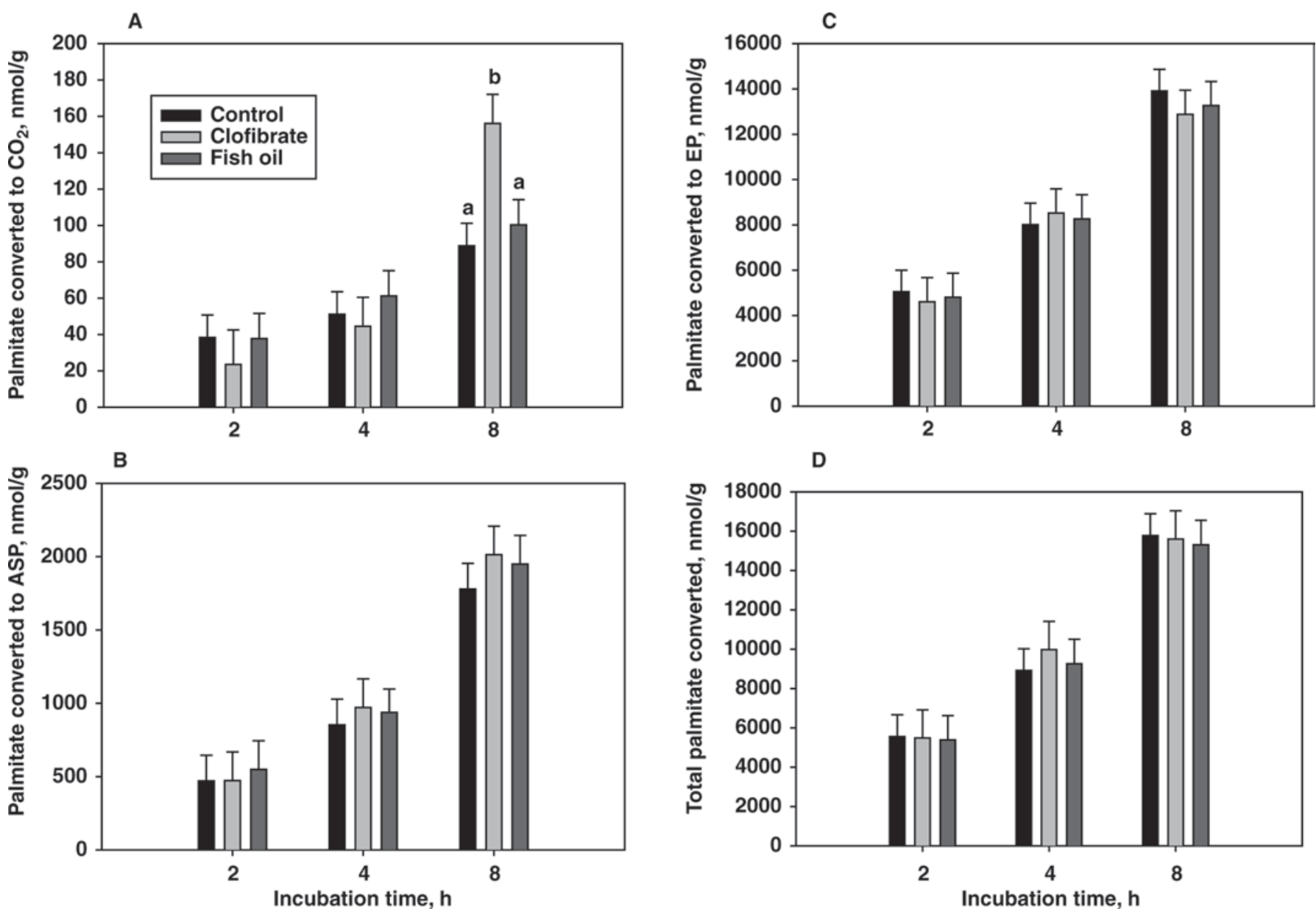

Figure 1. Least squares means and standard errors for metabolism of palmitate to $\mathrm{CO}_{2}$ (A), acid-soluble products (ASP; B), total esterified products $(\mathrm{EP} ; \mathrm{C})$, and total utilization $\left(\mathrm{CO}_{2}+\mathrm{ASP}+\mathrm{EP} ; \mathrm{D}\right)$ by liver slices from calves either untreated (control) or treated with clofibrate $(62.5 \mathrm{mg} / \mathrm{kg}$ of $\mathrm{BW})$ or fish oil $(250 \mathrm{mg} / \mathrm{kg}$ of $\mathrm{BW})$. A) Conversion to $\mathrm{CO}_{2}$. Differences among incubation times were significant $(P<0.05)$. The interaction of incubation time $\times$ treatment was significant $(P<0.05)$ because liver slices from calves treated with clofibrate converted more palmitate to $\mathrm{CO}_{2}$ during 8-h incubations than liver slices from control or fish oil-treated calves. Treatment effects were not significant $(P=$ 0.54). B) Conversion to ASP. Differences among incubation times were significant $(P<0.05)$. Treatment effects $(P=0.77)$ and the interaction of treatment $\times$ incubation time $(P=0.97)$ were not significant. C) Conversion to EP. Differences among incubation times were significant $(P$ $<0.05)$. Effects of treatment $(P=0.96)$ and the interaction of treatment $\times$ incubation time $(P=0.88)$ were not significant. D) Total metabolism. Differences among incubation times tended $(P=0.08)$ to be different. Effects of treatment $(P=0.97)$ and the interaction of treatment $\times$ incubation time $(P=0.95)$ were not significant.

goats (Cappon et al., 2002). Reasons for the minimal changes in liver palmitate or oleate metabolism caused by PPAR $\alpha$ agonist treatment of calves remain unclear. Potential alteration of clofibrate or fish oil by ruminal fermentation and absorption into the blood stream for presentation to the liver are unknown variables, which could affect the effectiveness of the treatments employed in this study. During a 4-d fast, intravenous infusions of fish oil emulsions in nonlactating Holstein cows increased total oxidation of $\left[1-{ }^{14} \mathrm{C}\right]$ oleic acid to ASP by liver homogenates compared with pretreatment and infusions of tallow (Mashek et al., 2005). However, infusion of fish oil resulted in no significant difference in peroxisomal oxidation (Mashek et al., 2005). Degree of saturation of LCFA in milk replacer affects hepatic metabolism in calves. Conversion of LCFA to $\mathrm{CO}_{2}$ was significantly lower and conversion to ASP tended $(P=$ 0.06 ) to be lower by liver slices from calves fed saturated fat from coconut oil compared with liver slices from calves fed less saturated beef tallow (Graulet et al., 2000). In a comparison of hepatic LCFA oxidation between rats and preruminant calves, the oxidation of $0.8 \mathrm{mM}$ oleate to $\mathrm{CO}_{2}$ and ASP in rat liver slices was 2.8 times and 2.1 times greater, respectively, than in calf liver slices (Graulet et al., 1998). Clofibrate increased rates of hepatic peroxisomal and mitochondrial $\beta$-oxidation of $\left[1-{ }^{14} \mathrm{C}\right]$ palmitate in pigs by 60 and $186 \%$, respectively (Peffer et al., 2005). Furthermore, malonyl- 

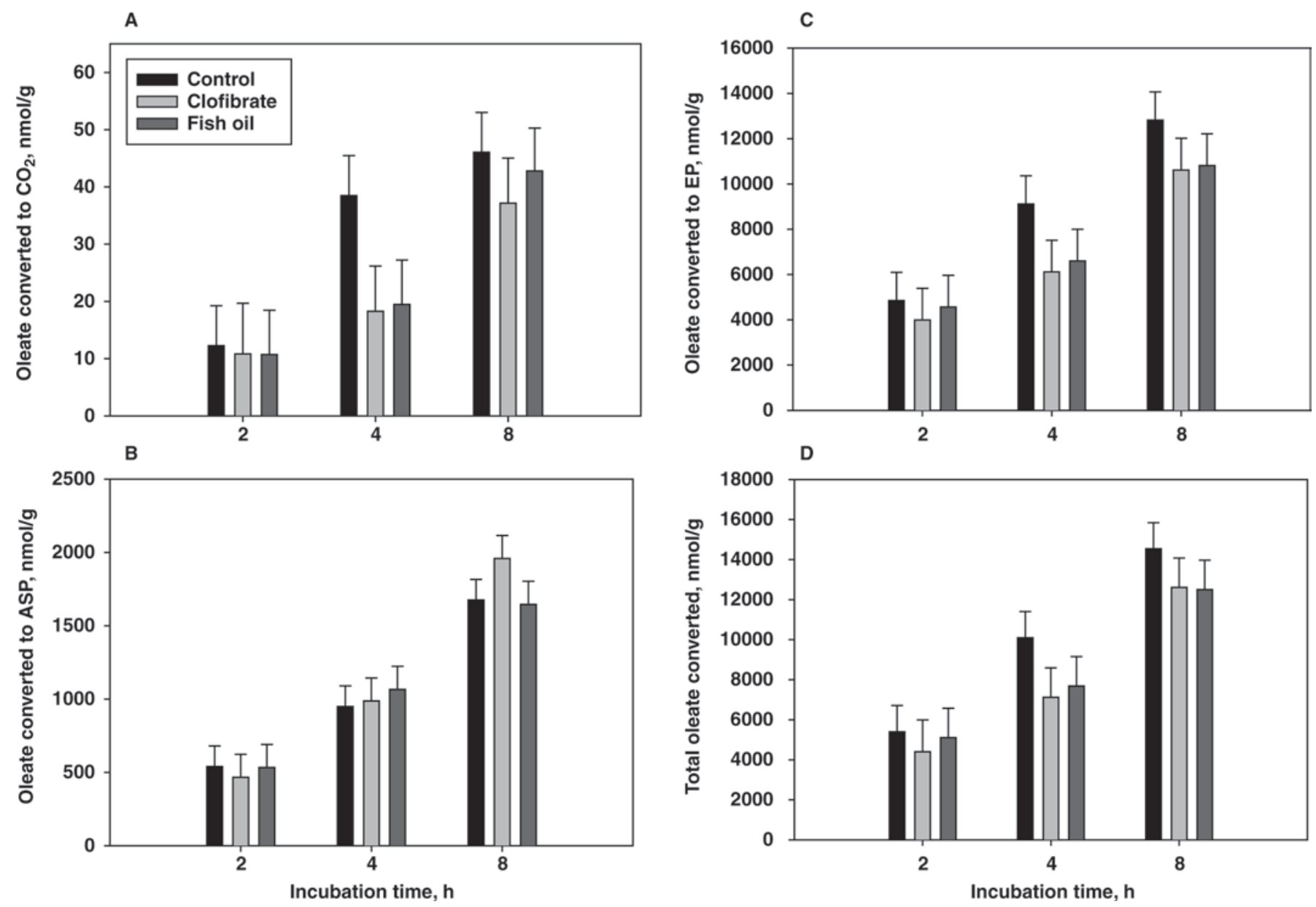

Figure 2. Least squares means and standard errors for metabolism of oleate to $\mathrm{CO}_{2}$ (A), acid-soluble products (ASP; B), total esterified products $(\mathrm{EP} ; \mathrm{C})$, and total utilization $\left(\mathrm{CO}_{2}+\mathrm{ASP}+\mathrm{EP} ; \mathrm{D}\right)$ by liver slices from calves either untreated (control) or treated with clofibrate $\left(62.5 \mathrm{mg} / \mathrm{kg}\right.$ of BW) or fish oil $\left(250 \mathrm{mg} / \mathrm{kg}\right.$ of BW). A) Conversion to $\mathrm{CO}_{2}$. Differences among incubation times were significant $(P<0.05)$. Effects of treatment $(P=0.19)$ and the interaction of treatment $\times$ incubation time $(P=0.59)$ were not significant. B) Conversion to ASP. Effects of treatment $(P=0.88)$ and the interaction of treatment $\times$ incubation time $(P=0.45)$ were not significant. C) Conversion to EP. Differences among incubation times were significant $(P<0.05)$. Effects of treatment $(P=0.44)$ and the interaction of treatment $\times$ incubation time $(P=0.63)$ were not significant. D) Total metabolism. Differences among incubation times were significant $(P<0.05)$. Effects of treatment $(P=0.48)$ and the interaction of treatment $\times$ incubation time $(P=0.72)$ were not significant.

CoA-sensitive CPT-1 activity increased $64 \%$ in pigs receiving clofibrate (Peffer et al., 2005).

Although not compared directly in this experiment, rates of in vitro metabolism of palmitate by liver slices from calves in the current study were approximately 10 times greater than rates observed in previous studies using liver slices from adult nonlactating and lactating dairy cows under identical conditions in the same in vitro system (Litherland et al., 2003). Hepatocytes of calves 2 wk after weaning may be more adapted to oxidation of LCFA from the high-fat diet of milk or milk replacer fed previously and thus have greater capacity to metabolize LCFA. Calves on a diet of milk replacer and starter would be consuming a greater proportion of calories as fat and thus may be adapted to greater rates of oxidation of LCFA when compared with adult dairy cows that are typically fed relatively low-fat diets. Therefore, effects of test compounds might be anticipated to be greater in liver from mature cattle in which rates of palmitate or oleate metabolism are inherently lower. Additionally, application of PPAR $\alpha$ agonist compounds in periparturient cows mobilizing large amounts of adipose TAG may offer a better environment for testing the effects of these compounds.

Analysis of specific mRNA abundance revealed that treatment of calves with clofibrate significantly increased $A C A D V L, A C S L 1$, and $C Y P 4 A 11$ and tended $(P<0.10)$ to increase $A C O X 1$ and $C P T 1 A$ (Figure 3). Treatment with fish oil had no effect on abundance of mRNA for these genes. All of these genes are known to be under the control of PPAR $\alpha$ in other species (Mandard et al., 2004), suggesting that clofibrate acted on 
Table 7. Least squares means for metabolism of palmitate to carbon dioxide $\left(\mathrm{CO}_{2}\right)$, acid-soluble products (ASP), and esterified products (EP), expressed as percentages of total palmitate metabolism

\begin{tabular}{|c|c|c|c|c|c|c|c|}
\hline \multirow[b]{2}{*}{$\begin{array}{l}\text { Variable, } \% \\
\text { of total metabolism }\end{array}$} & \multicolumn{3}{|c|}{ Treatment $^{1}$} & \multirow[b]{2}{*}{$\mathrm{SE}$} & \multicolumn{3}{|c|}{$P$-value } \\
\hline & Control & Clofibrate & Fish oil & & Treatment & $\begin{array}{l}\text { Incubation } \\
\text { time }\end{array}$ & $\begin{array}{l}\text { Treatment } \times \\
\text { incubation time }\end{array}$ \\
\hline \multicolumn{8}{|l|}{$\mathrm{CO}_{2}$} \\
\hline $2 \mathrm{~h}$ & 0.70 & 0.43 & 0.63 & 0.14 & 0.90 & 0.10 & 0.05 \\
\hline $4 \mathrm{~h}$ & 0.57 & 0.45 & 0.70 & 0.14 & & & \\
\hline $8 \mathrm{~h}$ & 0.60 & 1.00 & 0.68 & 0.14 & & & \\
\hline $4 \mathrm{~h}$ & 9.56 & 10.92 & 10.01 & 1.43 & & & \\
\hline $8 \mathrm{~h}$ & 10.78 & 13.42 & 12.43 & 1.43 & & & \\
\hline \multicolumn{8}{|l|}{$\mathrm{EP}$} \\
\hline $2 \mathrm{~h}$ & 90.86 & 89.63 & 89.47 & 1.47 & 0.18 & 0.01 & 0.91 \\
\hline $4 \mathrm{~h}$ & 89.86 & 88.64 & 89.30 & 1.47 & & & \\
\hline $8 \mathrm{~h}$ & 88.61 & 85.58 & 86.92 & 1.47 & & & \\
\hline
\end{tabular}

${ }^{1}$ Calves received a treatment of control (untreated), clofibrate $(62.5 \mathrm{mg} / \mathrm{kg}$ of BW), or fish oil (250 mg/kg of BW) for a 5 -d treatment period.

the liver of our calves to increase oxidative capacity in mitochondria (e.g., increased $A C A D V L$ and the tendency for increased $C P T 1 A$ ) and microsomes (e.g., increased $C Y P 4 A 11)$. In addition, our data indicated greater capacity for LCFA activation through increased ACSL1 as well as a tendency for increased peroxisomal oxidation of LCFA (e.g., increased ACOX1) in calves treated with clofibrate. Fish oil evidently did not lead to activation of PPAR $\alpha$ in calf liver, but rather tended $(P<0.08)$ to increase capacity for synthesis of TAG (e.g., increased $D G A T 1)$. Overall, these data provide support for the modestly greater in vitro palmitate oxidation capacity observed in liver slices from clofibrate-treated calves; in contrast, fish oil did not affect oxidative capacity for LCFA, but tended to increase capacity for esterification.

Data from this study partly support recent in vitro findings in experiments using MDBK cells treated with the PPAR $\alpha$ agonist $\mathrm{Wy}-14,643$ or individual LCFA [Bi- onaz et al., 2008; Thering et al., 2009; M. Bionaz, B. J. Thering (University of Illinois, Urbana), and J. J. Loor, unpublished data]. In MDBK cells, the expression of $A C S L 1, A C A D V L$, and $C P T 1 A$ was significantly increased by $\mathrm{Wy}-14,643$; however, the response was very large compared with the in vivo effects observed in calf liver in the present experiment (Bionaz et al., 2008; Thering et al., 2009). In MDBK cells, the expression of $A C O X 1$ was not affected by $\mathrm{Wy}-14,643$, but in the current study, $A C O X 1$ tended $(P<0.07)$ to be moderately upregulated in calf liver by clofibrate. Clofibrate and Wy-14,643 have similar effects on liver transcriptomics, with Wy-14,643 having more potent effects (judging from large-scale gene expression analysis) in rodents (Tamura et al., 2006). Thus, the lack of response of ACOX1 to $\mathrm{Wy}-14,643$ by kidney cells in vitro and the response to the less potent agonist clofibrate in liver in vivo remain to be reconciled.

Table 8. Least squares means and standard errors for metabolism of oleate to carbon dioxide $\left(\mathrm{CO}_{2}\right)$, acid-soluble products (ASP), and esterified products (EP), expressed as percentages of total oleate metabolism

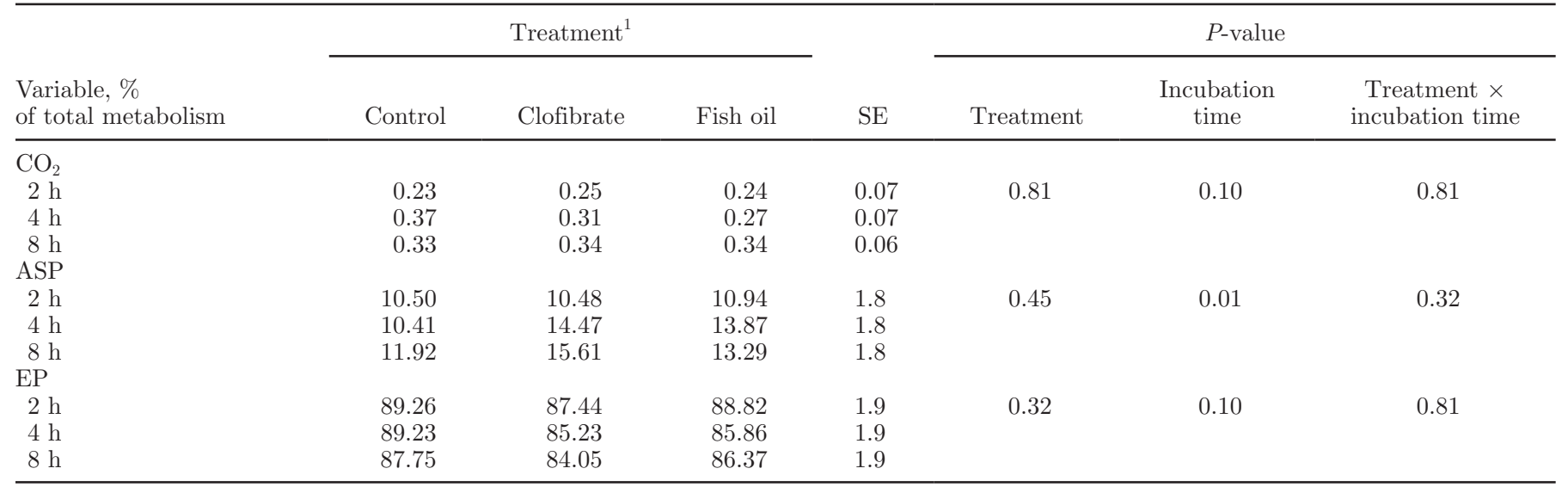

${ }^{1}$ Calves received a treatment of control (untreated), clofibrate $(62.5 \mathrm{mg} / \mathrm{kg}$ of BW), or fish oil $(250 \mathrm{mg} / \mathrm{kg}$ of BW) for a 5 -d treatment period. 


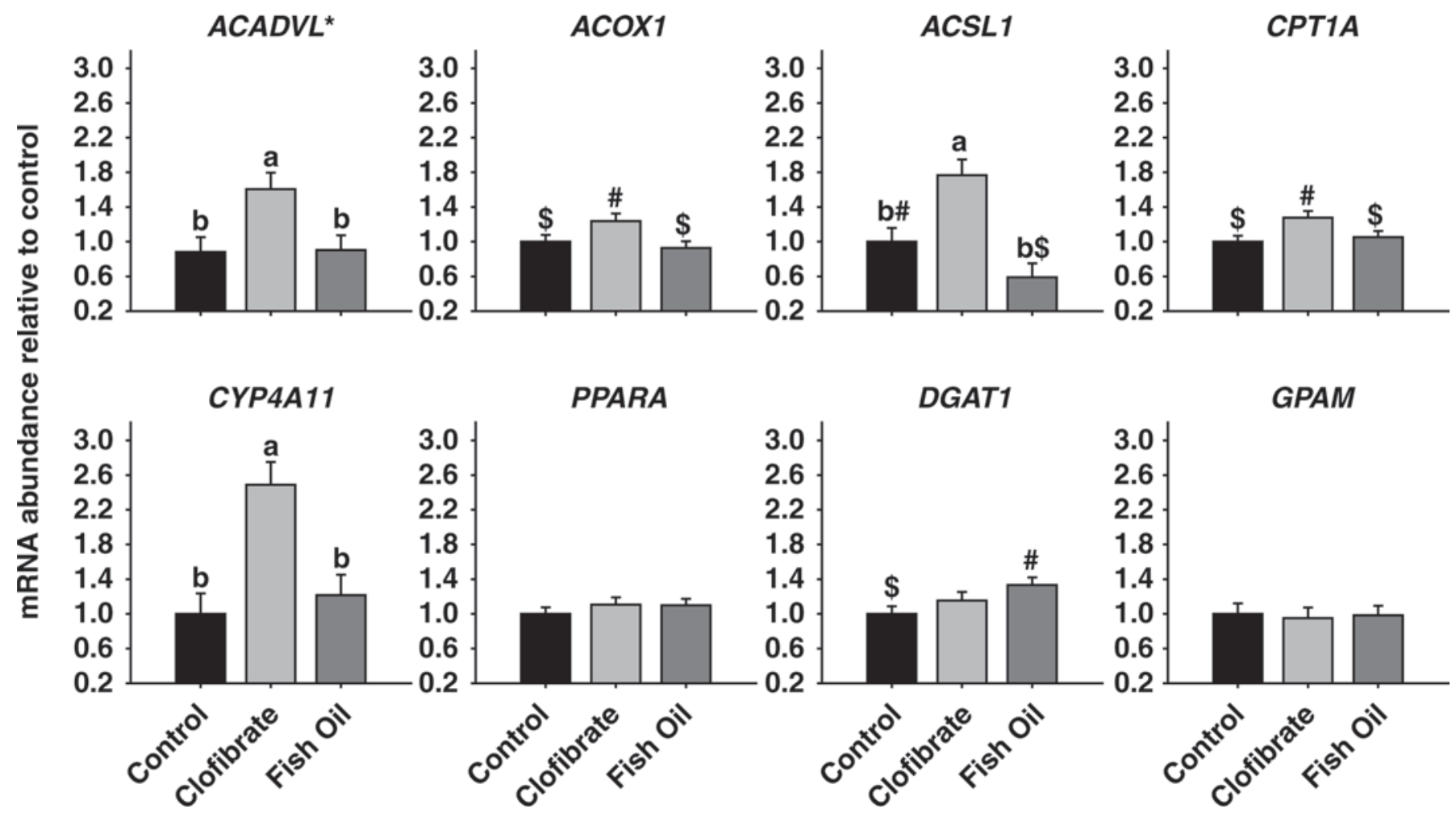

Figure 3. The mRNA abundance of 6 potential peroxisome proliferator-activated receptor- $\alpha($ PPAR $\alpha)$ target genes $[A C A D V L=$ acylcoenzyme A dehydrogenase, very long chain; $A C O X 1$ = acyl-coenzyme A oxidase 1, palmitoyl; ACSL1 = acyl-coenzyme A synthetase long-chain family member $1 ; C P T 1 A=$ carnitine palmitoyltransferase $1 \mathrm{~A}$ (liver); $C Y P 4 A 11=$ cytochrome P450, family 4 , subfamily A, polypeptide 11 ; PPARA = peroxisome proliferator-activated receptor- $\alpha]$ and 2 genes involved in lipid synthesis $(D G A T 1=$ diacylglycerol O-acyltransferase homolog 1; GPAM = glycerol-3-phosphate acyltransferase, mitochondrial) relative to control (untreated calves) in liver of weaned male Holstein calves treated with clofibrate or fish oil. Values are least squares means \pm standard errors of the mean. The effect of treatment was significant $(P$ $<0.05)$ for $A C A D V L, A C S L 1$, and $C Y P 4 A 11$, and tended $(P<0.10)$ to be significant for ACOX1, CPT1A, and DGAT1. Letters $(\mathrm{a}$, b) denote significant difference $(P<0.05)$ and symbols $(\#, \$)$ denote tendencies $(P<0.10)$ among treatments. Asterisk indicates that $A C A D V L$ data are reported as least squares means \pm standard errors of the mean of $\log _{10}$-transformed data +1 (see Materials and Methods).

The lack of response of the measured genes to fish oil treatment in the present experiment was unexpected. Rodents fed diets containing fish oil had a large increase in expression of PPAR $\alpha$ target genes (Larter et al., 2008). In MDBK cells, the 2 polyunsaturated LCFA highly enriched in fish oil, eicosapentaenoic and docosahexaenoic acids (Table 2), had effects similar to Wy-14,643 on several PPAR $\alpha$ target genes, with eicosapentaenoic acid having the greatest effects $[\mathrm{M}$. Bionaz, B. J. Thering (University of Illinois, Urbana), and J. J. Loor; unpublished data]. In the MDBK experiments (Bionaz et al., 2008; Thering et al., 2009), saturated LCFA were clearly stronger PPAR $\alpha$ activators than either Wy-14,643 or unsaturated LCFA. Previous in vitro experiments with calf hepatocytes yielded conflicting data when cells were incubated with eicosapentaenoic or docosahexaenoic acids. In short-term suspension cultures of calf hepatocytes, these LCFA were oxidized to $\mathrm{CO}_{2}$ at approximately 2 to 3 times the rates of palmitate or oleate, but were esterified to a much lesser de- gree than palmitate or oleate (Mashek et al., 2002). By contrast, in longer term (48-h) monolayer cultures of calf hepatocytes, eicosapentaenoic and docosahexaenoic acids decreased palmitate oxidation to ASP and eicosapentaenoic decreased incorporation of palmitate into esterified lipids (Mashek and Grummer, 2003). Thus, it is becoming evident that LCFA metabolism in bovine tissues may be regulated more by changes in saturated LCFA availability than by polyunsaturated LCFA as in rodents (Mashek and Grummer, 2003; Thering et al., 2009).

Delivery of fish oil to the reticulo-rumen resulted in an unknown amount of polyunsaturated fatty acids reaching the small intestine. The unsaturated LCFA in fish oil may be extensively biohydrogenated in the rumen (Castañeda-Gutiérrez et al., 2007); thus, the profile of LCFA reaching the intestine for absorption in the current study is not known. The relative ability of potential intermediates and saturated end products of fish oil biohydrogenation to activate PPAR $\alpha$ and induce 
PPAR $\alpha$ target genes compared with eicosapentaenoic and docosahexaenoic acids is not known. However, partially hydrogenated fish oil is well known to activate expression of PPAR $\alpha$ target genes in liver when fed to rats (e.g., Flatmark et al., 1988). Regardless of the extent of biohydrogenation, therefore, dietary fish oil could be expected to affect hepatic LCFA metabolism, but these effects were minimal in the present experiment.

The gene expression response of liver from calves treated with clofibrate, together with physiological and in vitro measurements, indicates that the PPAR $\alpha$ agonist had an effect on bovine liver, although the response was considerably less robust than in liver of rodent models (Kramer et al., 2003). The modest responses of PPAR $\alpha$ target genes in clofibrate-supplemented calves contrast with the extremely large response to clofibrate and other PPAR $\alpha$ agonists observed in rats and mice (Tamura et al., 2006). This relative response would place the bovine with other species that exhibit modest responses to PPAR a agonists, including dogs and guinea pigs (Meyer et al., 1999) as well as pigs (Yu et al., 2001; Cheon et al., 2005). However, this apparent species difference must be tempered by several unknown factors with respect to bovine liver. First, the liver may have been only in the initial phase of response to the compound because BHBA responses were minimal despite a similar concentration of NEFA in plasma and a lack of decrease in liver TAG. Second, the appropriate dosage and absorption of clofibrate from the digestive tract of calves is not known. In the present experiment the assimilation and availability of clofibrate for the liver as indicated by plasma concentration was not assessed. Therefore, even though the present data demonstrate a response of ruminant liver to clofibrate, longer term experiments and dose-response experiments to analyze the time course of adaptation together with the evaluation of clofibrate availability for the liver would be necessary to assess the true magnitude of response.

\section{CONCLUSIONS}

Our data indicated that in vivo administration of clofibrate to weaned dairy calves resulted in greater abundance compared with controls of mRNA for 5 genes known to be responsive to PPAR $\alpha$ activation in nonruminants (ACADVL, ACSL1, CPT1A, CYP4A11, and $A C O X 1)$. Clofibrate modestly increased rates of oxidation of palmitate in liver slices. Thus, bovine liver responds to PPAR $\alpha$ agonists, at least clofibrate, but perhaps less strongly than in rodents. Dose-response studies would be needed to determine whether effects observed in this experiment represented maximal responses to clofibrate. Fish oil administered into the ru- men had minimal effects on in vitro LCFA metabolism in liver or on abundance of specific mRNA, with the exception of modest increases in DGAT1. Treatments had minimal effects on liver weight, plasma metabolites and enzymes, or other indicators of liver function measured. Administration of PPAR $\alpha$ agonists might stimulate an ancillary route for the oxidation of LCFA by increasing both peroxisomal and mitochondrial pathways. Such an effect might help to minimize hepatic TAG accumulation, particularly in periparturient dairy cows.

\section{ACKNOWLEDGMENTS}

The authors appreciate the kind donation of fish oil by Omega Protein (Hammond, LA).

\section{REFERENCES}

Akbiyik, F., K. Cinar, T. Ozsullu, E. Demirpence, R. Tunca, R. Haziroglu, O. Onder, S. Civris, C. Yurdaydin, O. Uzunalimoglu, and H. Bozkaya. 2003. Peroxisome proliferator activated receptoralpha (PPAR-alpha) expression is induced but peroxisomal enzyme response to clofibrate is blunted in a rat model of fatty liver. J. Hepatol. 38(Suppl. 2):30.

Akbiyik, F., D. M. Ray, H. Bozkaya, and E. Demirpence. 2004. Ligandand species-dependent activation of PPAR- $\alpha$. Cell. Physiol. Biochem. 14:269-276.

Allain, C. C., L. S. Poon, C. S. Chan, W. Richmond, and P. C. Fu 1974. Enzymatic determination of total serum cholesterol. Clin. Chem. 20:470-475.

Bergmeyer, H. U., M. Horder, and R. Rej. 1986. International Federation of Clinical Chemistry (IFCC) Scientific Committee, Analytical Section: Approved recommendation (1985) on IFCC methods for the measurement of catalytic concentration of enzymes. Part 2. IFCC method for aspartate aminotransferase (L-asparate:2-oxoglutarate aminotransferase, EC 2.61.1). J. Clin. Chem. Clin. Biochem. 24:497-510.

Bionaz, M., C. R. Baumrucker, E. Shirk, J. P. Vanden Heuvel, E. Block, and G. A. Varga. 2008. Characterization of Madin-Darby bovine kidney cell line for peroxisome proliferator-activated receptors: Temporal response and sensitivity to fatty acids. J. Dairy Sci. 91:2808-2813.

Bionaz, M., and J. J. Loor. 2008. ACSL1, AGPAT6, FABP3, LPIN1, and SLC27A6 are the most abundant isoforms in bovine mammary tissue and their expression is affected by stage of lactation. J. Nutr. 138:1019-1024.

Cappon, G. D., R. C. M. Liu, S. R. Frame, and M. E. Hurtt. 2002 Effects of the rat hepatic peroxisome proliferator, Wyeth-14,643, on the lactating goat. Drug Chem. Toxicol. 25:255-266.

Carlson, D. B., N. B. Litherland, H. M. Dann, J. C. Woodworth, and J. K. Drackley. 2006. Metabolic effects of L-carnitine infusion and feed restriction in lactating Holstein cows. J. Dairy Sci. 89:48194834

Carlson, G. P. 1996. Clinical chemistry tests. Pages 441-469 in Large Animal Internal Medicine. 2nd ed. B. P. Smith, ed. Mosby-Year Book Inc., St. Louis, MO.

Castañeda-Gutiérrez, E., M. J. de Veth, A. L. Lock, D. A. Dwyer, K. D. Murphy, and D. E. Bauman. 2007. Effect of supplementation with calcium salts of fish oil on n-3 fatty acids in milk fat. J. Dairy Sci. 90:4149-4156.

Cheon, Y., T. Y. Nara, M. R. Band, J. E. Beever, M. A. Wallig, and M. T. Nakamura. 2005. Induction of overlapping genes by fasting and a peroxisome proliferator in pigs: Evidence of functional PPARalpha in nonproliferating species. Am. J. Physiol. 288:R1525-R1535.

Dokianakis, S. N., M. E. Kornaros, and G. Lyberatos. 2004. On the effect of pharmaceuticals on bacterial nitrite oxidation. Water Sci. Technol. 50:341-346. 
Douglas, G. N., J. Rehage, A. D. Beaulieu, A. O. Bahaa, and J. K. Drackley. 2007. Prepartum nutrition alters fatty acid composition in plasma, adipose tissue, and liver lipids of periparturient dairy cows. J. Dairy Sci. 90:2941-2959.

Drackley, J. K., and J. B. Andersen. 2006. Splanchnic metabolism of long-chain fatty acids in ruminants. Pages 199-224 in Ruminant Physiology: Digestion, Metabolism and Impact of Nutrition on Gene Expression, Immunology and Stress. Proceedings 10th International Symposium on Ruminant Physiology, Copenhagen, Denmark. K. Sejrsen, T. Hvelplund, and M. O. Nielsen, ed. Wageningen Academic Publishers, Utrecht, the Netherlands.

Drackley, J. K., D. C. Beitz, and J. W. Young. 1991. Regulation of in vitro oxidation in liver from dairy cows during early lactation. J. Dairy Sci. 74:1884-1892.

Drillia, P., K. Stamatelatou, and G. Lyberatos. 2005. Fate and mobility of pharmaceuticals in solid matrices. Chemosphere 60:1034-1044.

Flatmark, T., A. Nilsson, J. Kvannes, T. S. Eikhom, M. H. Fukami, H. Kryvi, and E. N. Christiansen. 1988. On the mechanism of induction of the enzyme systems for peroxisomal $\beta$-oxidation of fatty acids in rat liver by diets rich in partially hydrogenated fish oil. Biochim. Biophys. Acta 962:122-130.

Fletcher, M. J. 1968. A colorimetric method for estimating serum triglycerides. Clin. Chim. Acta 22:393-397.

Foster, L. B., and R. T. Dunn. 1973. Stable reagents for determination of serum triglycerides by a colorimetric Hantzsch condensation method. Clin. Chem. 19:338-340.

Fountoulakis, M., P. Drillia, K. Stamatelatou, and G. Lyberatos. 2004. Toxic effect of pharmaceuticals on methanogenesis. Water Sci. Technol. 50:335-340.

Graulet, B., D. Gruffat-Mouty, D. Durand, and D. Bauchart. 1998. Fatty acid metabolism and very low density lipoprotein secretion in liver slices from rats and preruminant calves. J. Biochem. 124:1212-1219.

Graulet, B., D. Gruffat-Mouty, D. Durand, and D. Bauchart. 2000. Effect of milk diets containing beef tallow or coconut oil on the fatty acid metabolism of liver slices from preruminant calves. Br. J. Nutr. 84:309-318.

Green, S. 1995. PPAR: A mediator of peroxisome proliferator action. Mutat. Res. 333:101-109.

Grum, D. E., J. K. Drackley, and J. H. Clark. 2002. Fatty acid metabolism in liver of dairy cows fed supplemental fat and nicotinic acid during an entire lactation. J. Dairy Sci. 85:3026-3034.

Grum, D. E., L. R. Hansen, and J. K. Drackley. 1994. Peroxisomal $\beta$-oxidation of fatty acids in bovine and rat liver. Comp. Biochem. Physiol. 109:281-292.

Hara, A., and N. S. Radin. 1978. Lipid extraction of tissue with a lowtoxicity solvent. Anal. Biochem. 90:420-426.

Janovick-Guretzky, N. A., H. M. Dann, D. B. Carlson, M. R. Murphy, J. J. Loor, and J. K. Drackley. 2007. Housekeeping gene expression in bovine liver is affected by physiological state, feed intake, and dietary treatment. J. Dairy Sci. 90:2246-2252.

Jesse, B. W., R. S. Emery, and J. W. Thomas. 1986. Control of bovine hepatic fatty acid oxidation. J. Dairy Sci. 69:2290-2297.

Johnson, M. M., and J. P. Peters. 1993. Technical note: An improved method to quantify nonesterified fatty acids in bovine plasma. J. Anim. Sci. 71:753-756.

Jones, P. A., J. J. Lea, and R. U. Pendlington. 1999. Investigation of the potential of conjugated linoleic acid (Cla) to cause peroxisome proliferation in rats. Food Chem. Toxicol. 37:1119-1125.

Kliewer, S. A., S. S. Sundseth, S. A. Jones, P. J. Brown, G. B. Wisely, C. S. Koble, P. Devchand, W. Wahli, T. M. Wilson, J. M. Lenhard, and J. M. Lehman. 1997. Fatty acids and eicosanoids regulate gene expression through direct interactions with peroxisome proliferator-activated receptors $\alpha$ and $\gamma$. Proc. Natl. Acad. Sci. USA 94:4318-4323.

Kramer, J. A., E. A. Blomme, R. T. Bunch, J. C. Davila, C. J. Jackson, P. F. Jones, K. L. K. Kolaja, and S. W. Curtiss. 2003. Transcription profiling distinguishes dose-dependent effects in the livers of rats treated with clofibrate. Toxicol. Pathol. 31:417-431.
Larter, C. Z., M. M. Yeh, J. Cheng, J. Williams, S. Brown, A. dela Pena, K. S. Bell-Anderson, and G. C. Farrell. 2008. Activation of peroxisome proliferator-activated receptor alpha by dietary fish oil attenuates steatosis, but does not prevent experimental steatohepatitis because of hepatic lipoperoxide accumulation. J. Gastroenterol. Hepatol. 23:267-275.

Lazarow, P. B., and C. De Duve. 1976. A fatty acid acyl-CoA oxidizing system in rat liver peroxiomes; Enhancement by clofibrate, a hypolipidemic drug. Proc. Natl. Acad. Sci. USA 73:2043-2046.

Lee, S. S. T., T. Pineau, J. Drago, E. J. Lee, J. W. Owens, D. L. Kroetz, P. M. Fernandez-Salguero, H. Westphal, and F. J. Gonzalez. 1995. Targeted disruption of the $\alpha$ isoform of the peroxisome proliferator-activated receptor gene in mice results in abolishment of the pleiotropic effects of peroxisome proliferators. Mol. Cell. Biol. 15:3012-3022.

Litherland, N. B., H. M. Dann, A. S. Hansen, and J. K. Drackley. 2003. Prepartum nutrient intake alters metabolism by liver slices from peripartal cows. J. Dairy Sci. 86(Suppl. 1):105-106.

Littell, R. C., G. A. Milliken, W. W. Stroup, and R. D. Wolfinger. 1996. SAS System of Mixed Models. SAS Institute, Cary, NC.

Lo, S., J. C. Russell, and A. W. Taylor. 1970. Determination of glycogen in small tissue samples. J. Appl. Physiol. 28:234-236.

Loor, J. J., H. M. Dann, R. E. Everts, R. Oliveira, C. A. Green, N. A. Janovick-Guretzky, S. L. Rodriguez-Zas, H. A. Lewin, and J. K. Drackley. 2005. Temporal gene expression profiling of liver from periparturient dairy cows reveals complex adaptive mechanisms in hepatic function. Physiol. Genomics 23:217-226.

Mandard, S., M. Müller, and S. Kersten. 2004. Peroxisome proliferatoractivated receptor alpha target genes. Cell. Mol. Life Sci. 61:393416

Mannaerts, G. P., L. J. Debeer, J. Thomas, and P. J. DeSchepper. 1979. Mitochondrial and peroxisomal fatty acid oxidation in liver homogenates and isolated hepatocytes from control and clofibrate treated rats. J. Biol. Chem. 254:4585-4595.

Mashek, D. G., S. J. Bertics, and R. R. Grummer. 2002. Metabolic fate of long-chain unsaturated fatty acids and their effects on palmitic acid metabolism and gluconeogenesis in bovine hepatocytes. J. Dairy Sci. 85:2283-2289.

Mashek, D. G., S. J. Bertics, and R. R. Grummer. 2005. Effects of intravenous triacylglycerol emulsions on hepatic metabolism and blood metabolites in fasted dairy cows. J. Dairy Sci. 88:100109

Mashek, D. G., and R. R. Grummer. 2003. Effects of long chain fatty acids on lipid and glucose metabolism in monolayer cultures of bovine hepatocytes. J. Dairy Sci. 86:2390-2396.

Meyer, K., A. Völkl, R. Endele, H. F. Kühnle, and J. Pill. 1999. Species differences in induction of hepatic enzymes by BM 17.0744, an activator of peroxisome proliferator-activated receptor alpha (PPARalpha). Arch. Toxicol. 73:440-450.

Osmundsen, H., J. Bremer, and J. I. Pedersen. 1991. Metabolic aspects of peroxisomal $\beta$-oxidation. Biochim. Biophys. Acta 1085:141158

Peffer, P. L., X. Lin, and J. Odle. 2005. Hepatic $\beta$-oxidation and carnitine palmitoyltransferase-I in neonatal pigs after dietary treatments of clofibric acid, isoproterenol, and medium-chain triglycerides. Am. J. Physiol. 288:R1518-R1524.

Pennacchiotti, G. L., N. P. Rotstein, and M. I. Aveldano. 1996. Effects of clofibrate on lipids and fatty acids of mouse liver. Lipids 2:179 185.

Persijn, J. P., and W. van der Slik. 1976. A new method for the determination of gamma-glutamyltransferase in serum. J. Clin. Chem. Clin. Biochem. 14:421-427.

Peterson, J. I., and D. S. Young. 1968. Evaluation of the hexokinase/ glucose-6-phospate dehydrogenase method of determination of glucose in urine. Anal. Biochem. 23:301-316.

Piepenbrink, M. S., and T. R. Overton. 2003. Liver metabolism and production of cows fed increasing amounts of rumen-protected choline during the periparturient period. J. Dairy Sci. 86:17221733 . 
Qu, B., B. Halliwell, C. N. Ong, B. L. Lee, and Q. T. Li. 2000. Caloric restriction prevents oxidative damage induced by the carcinogen clofibrate in mouse liver. FEBS Lett. 473:85-88.

Rose, C. I., and A. R. Henderson. 1975. Reaction-rate assay of serum sorbitol dehydrogenase activity at 37 degrees C. Clin. Chem. 21:1619-1626.

Rukkwamsuk, T., M. J. H. Geelen, T. A. M. Kruip, and T. Wensing. 2000. Interrelation of fatty acid composition in adipose tissue, serum, and liver of dairy cows during the development of fatty liver postpartum. J. Dairy Sci. 83:52-59.

Schoonjans, K., J. Peinado-Onsurbe, A. Lefebvre, R. A. Heyman M. Briggs, S. Deeb, B. Staels, and J. Auwerx. 1996. PPAR $\alpha$ and PPAR $\delta$ activators direct a distinct tissue-specific transcriptional response via a PPRE in the lipoprotein lipase gene. EMBO J. 15:5336-5348.

Shoda, T., K. Mitsumori, H. Onodera, K. Toyoda, C. Uneyama, T. Imazawa, and M. Hirose. 1999. The relationship between decrease in $\mathrm{C} \times 32$ and induction of $\mathrm{P} 450$ isozymes in the early phase of clofibrate hepatocarcinogenesis in the rat. Arch. Toxicol. 73:373380 .

Studer, V. A., R. R. Grummer, and S. J. Bertics. 1993. Effect of prepartum propylene glycol administration on periparturient fatty liver in dairy cows. J. Dairy Sci. 76:2931-2939.

Sukhiha, P. S., and D. L. Palmquist. 1988. Rapid method for determination of total fatty acid content and composition of feedstuffs and feces. J. Agric. Food Chem. 36:1202-1206.

Talke, H., and G. E. Schubert. 1965. Enzymatic urea determination in the blood and serum in the Warburg optical test. Klin. Wochenschr. 43:174-175.
Tamura, K., A. Ono, T. Miyagishima, T. Nagao, and T. Urushidani. 2006. Profiling of gene expression in rat liver and rat primary cultured hepatocytes treated with peroxisome proliferators. J. Toxicol. Sci. 31:471-490.

Thering, B. J., M. Bionaz, and J. J. Loor. 2009. Long-chain fatty acid effects on peroxisome proliferator-activated receptor-alpharegulated genes in Madin-Darby bovine kidney cells: Optimization of culture conditions using palmitate. J. Dairy Sci. 92:20272037.

Tietz, N. W., A. D. Rinker, and L. M. Shaw. 1983. IFCC methods for the measurement of catalytic concentration of enzymes. Part 5. IFCC method for alkaline optimum, EC 3.13.1. J. Clin. Chem. Clin. Biochem. 21:731-748.

Wahlefeld, A. W., G. Herz, and E. Bernt. 1972. Modification of the Malloy-Evelyn method for a simple, reliable determination of total bilirubin in serum. Scand. J. Clin. Lab. Invest. 29(Suppl. 126):11-12.

Weichselbaum, T. E. 1945. An accurate and rapid method for the determination of proteins in small amounts of blood serum and plasma. Am. J. Clin. Pathol. 16:40-49.

Williamson, D. H., and J. Mellanby. 1974. D-(-)-3-hydroxybutyrate. Pages 1836-1840 in Methods of Enzymatic Analysis. Vol. 4. H. U. Bergmeyer, ed. Academic Press, London, UK.

Yu, X. X., J. Odle, and J. K. Drackley. 2001. Differential induction of peroxisomal $\beta$-oxidation enzymes by clofibric acid and aspirin in piglet tissues. Am. J. Physiol. 281:R1553-R1561. 